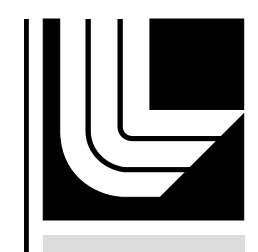

LAWRENCE LIVERMORE NATIONAL LABORATORY
A SUMMARY OF TEST OBSERVATIONS WHEN IBUTTONS ARE SUBJECTED TO RF ENERGY

R. J. Kane, E. V. Baluyot

December 21, 2011 
This document was prepared as an account of work sponsored by an agency of the United States government. Neither the United States government nor Lawrence Livermore National Security, LLC, nor any of their employees makes any warranty, expressed or implied, or assumes any legal liability or responsibility for the accuracy, completeness, or usefulness of any information, apparatus, product, or process disclosed, or represents that its use would not infringe privately owned rights. Reference herein to any specific commercial product, process, or service by trade name, trademark, manufacturer, or otherwise does not necessarily constitute or imply its endorsement, recommendation, or favoring by the United States government or Lawrence Livermore National Security, LLC. The views and opinions of authors expressed herein do not necessarily state or reflect those of the United States government or Lawrence Livermore National Security, LLC, and shall not be used for advertising or product endorsement purposes.

This work performed under the auspices of the U.S. Department of Energy by Lawrence Livermore National Laboratory under Contract DE-AC52-07NA27344. 


\section{A SUMMARY OF TEST OBSERVATIONS WHEN IBUTTONS ARE SUBJECTED TO RF ENERGY}

R. Kane

E. Baluyot

Engineering / NSED

Lawrence Livermore National Laboratory

Livermore CA 94551

20 Oct 2011 


\section{SUMMARY}

The iButton is a "one-wire", temperature sensor and data logger in a short metal cylinder package $17 \mathrm{~mm}$ in diameter and $6 \mathrm{~mm}$ tall. The device is designed to be attached to a surface and acquire temperature samples over time periods as short as 1 second to as long as 300 minutes. Both 8-bit and 16-bit samples are available with 8kB of memory available. Lifetime is limited to an internal battery that cannot be replaced or recharged.

The RF test interest originated with the concern that the data logger could inadvertently record electrical emanations from other nearby equipment. The normal operation of the data logger does not support high speed sampling but the control interface will operate at either 15.4 kbps or $125 \mathrm{kbps}$.

There were no observable effects in the operation of the module or in the data that could be attributed to the use of RF energy. We made the assumption that these devices would potentially show RF sensitivity in any of the registers and in the data memory equally, therefore gross changes in the data might show RF susceptibility. No such sensitivity was observed. Because significant power levels were used for these tests we can extrapolate downward in power to state that no RF susceptibility would occur at lower power levels given the same configurations.

\section{MOTIVATION}

The iButton would make a convenient long term environment-recording device but there is a concern regarding recording devices that may inadvertently record data related to sensitive, critical operations. A representative collection of iButton units were subjected to a variety of RF susceptibility tests to determine if there was any change in the memory or control registers. RF power levels from 1 to 200 watts were used in the frequency range of $100 \mathrm{kHz}$ to as high as $3 \mathrm{GHz}$ with three different system configurations required.

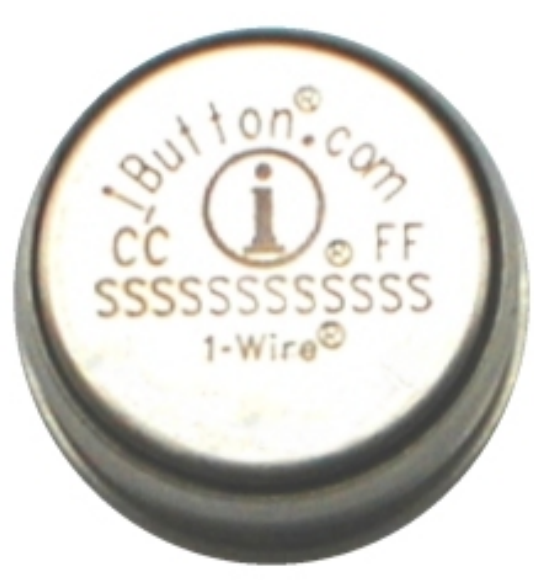

Figure 1. An example of an iButton, $17 \mathrm{~mm}$ diameter, $6 \mathrm{~mm}$ tall

\section{TEST Methodology}

The primary goal was to determine if the iButton was susceptible to RF energy at a moderate power level. We used three different test configurations to subject the device to RF electric fields; an enclosed TEM field cell, a low frequency dual ridge "horn style" antenna (EMCO) and a higher frequency Pyramidal Horn antenna (Amplifier 
Research). Power levels of 1 watt to 200 watts were used with the iButton orientation being adjusted to apply the fields in different directions across "cap" and "body" electrical connections.

Two sets of iButtons were available for test. A sample of 35 modules that had been used over a period of time prior to this testing and constitute the ensemble of 'Old' iButtons, a larger number of 'new' iButtons were also received but not all were used in testing. The test protocols for the two sets of modules are described separately in the following sections.

\section{OLD IBUTTONS}

An ensemble of 35 used iButtons were received for evaluation, these units had been in operation and acquired temperature data in an unspecified environment from $2 / 23 / 11$ into $3 / 9 / 11$. Some of the iButtons were configured for 8-bit sampling and the others set for 16-bits, the difference is that 8-bit data samples allow the maximum of 8192 separate temperature samples. The 'old' iButtons were set for 5 minute interval sampling. The User Interface for the iButtons does not allow downloading the entire contents as a single file that could make comparison somewhat simpler, rather, the control registers and data log are separate. Our assessment of the susceptibility of an iButton is based on general observation of the data and not an examination of the least significant bit which might be the most sensitive indicator if the sensor-to-ADC portion of the module was affected. We are making the assumption that if the device is susceptible then we might see changes in its operation or random changes to the data log.

Upon receipt, the data from all 35 units was archived. The RF testing protocol for these iButtons is listed in Table A1 of the Appendix, the test equipment is listed in Table A3. The focus was on whether the iButtons exhibited any tendency for RF Susceptibility and moderate power levels. An example of the stored temperature data appears in Figure 2. This data does not show any before-and-after differences and the internal control parameters were also the same before-and-after, the conclusion is that there is no susceptibility when using the protocol listed.

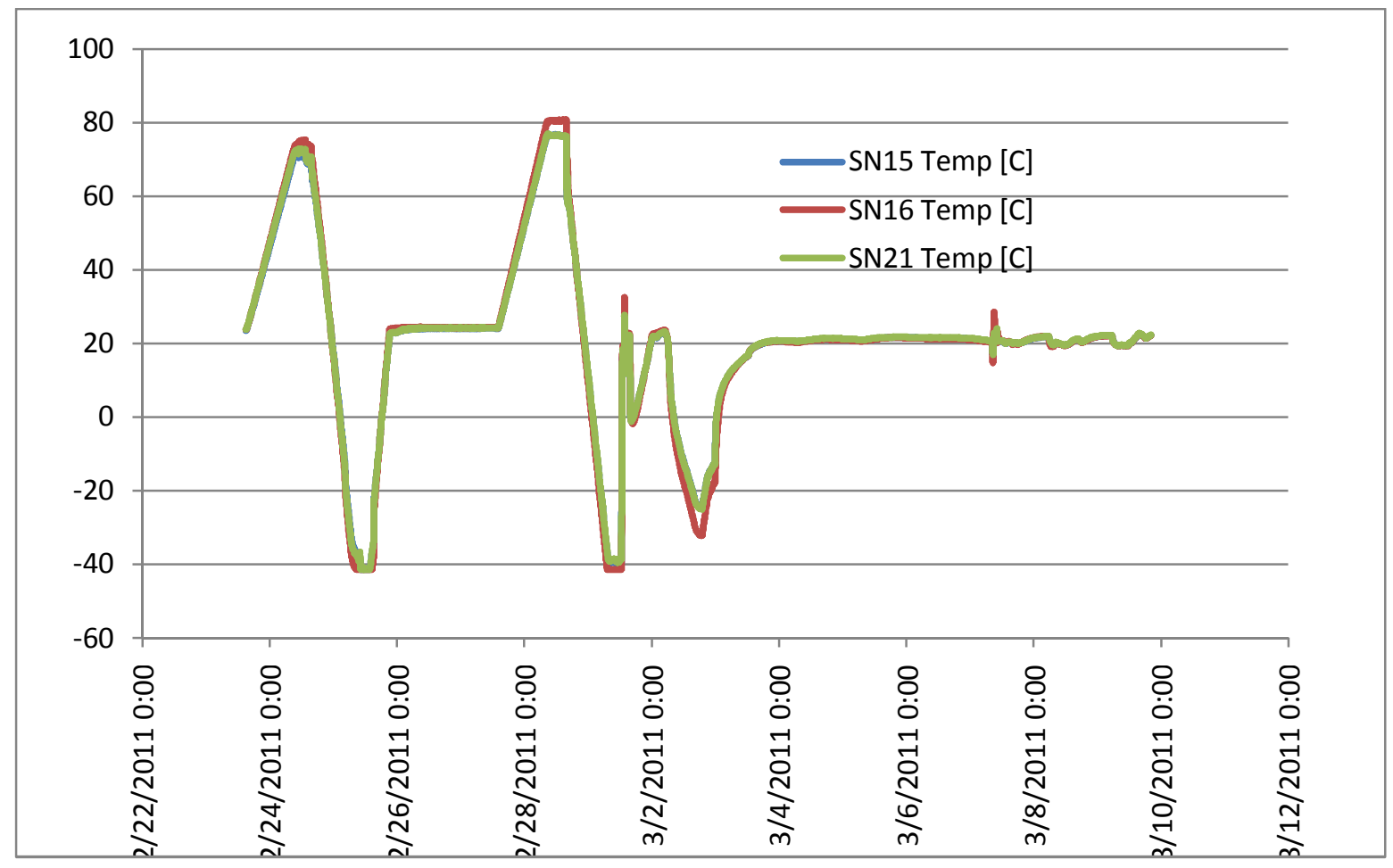


Figure 2. "Old" iButton data (16-bit) following RF exposures.

No difference noted in comparison of the before and after data sets. Five minute interval sampling.

Figure 3 shows the mounting of the iButtons on the access plate from the TEM cell. This applied the E-Field from the grounded wall to the cap contact on the top of the button. Other test configurations show the orientation where the E-Field is parallel to the interface of the iButton body and cap, this is less likely to couple but the distances are small making coupled fields small in the first place.

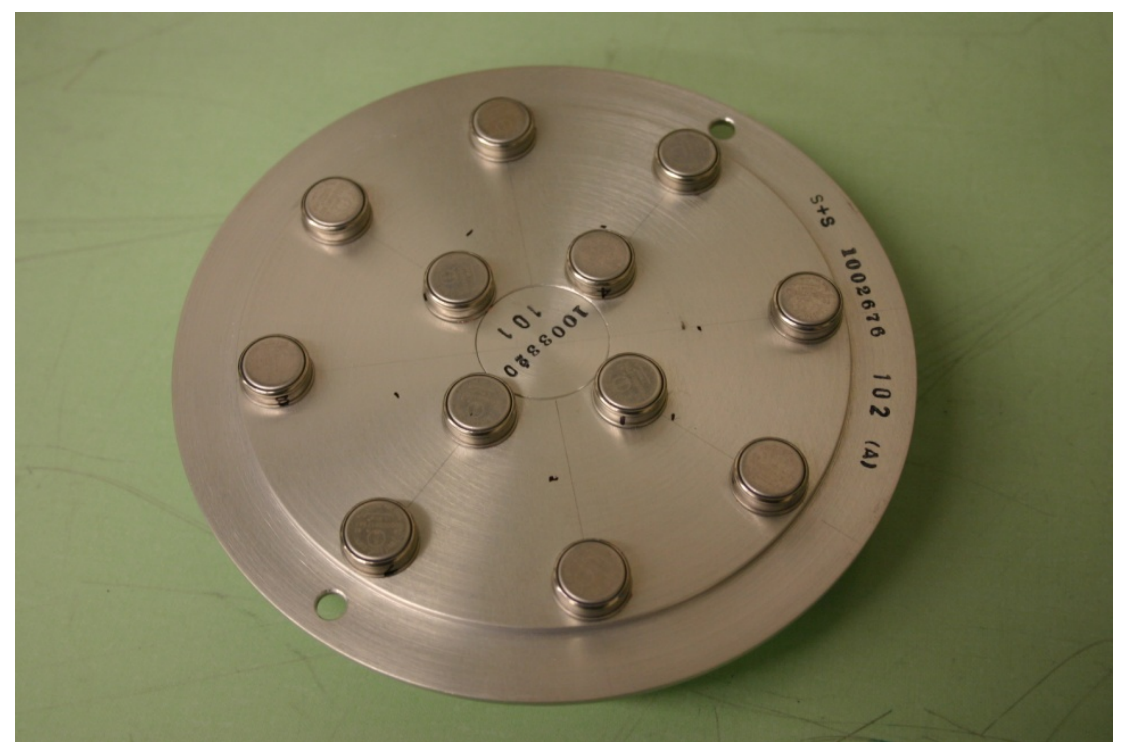

\section{Figure 3. iButtons mounted on the TEM cell access plate for E-Field testing}

The two antennas employed have gain and the power density on the test device is significant. Consider the application of 200 watts at a distance of $2 \mathrm{~m}, 10 \mathrm{~dB}$ gain (minimum) and a beamwidth estimate of 30 degrees; the power density estimate is $60 \mathrm{mw} / \mathrm{cm}^{\wedge} 2$ (about the size of the module as well) and the antenna manufacturer's Efield estimate is greater than $100 \mathrm{~V} / \mathrm{m}$. Table A4 summarizes the electric field levels for the TEM cell and antennas as a function of frequency and power. The RF levels are well above those normally employed for electromagnetic compliance (EMC) testing that is more typically $10 \mathrm{~V} / \mathrm{m}$.

Figure 4 shows the iButtons when mounted to the inside of the TEM cell. The applied field is from the septum at the bottom to the grounded wall at the top. 


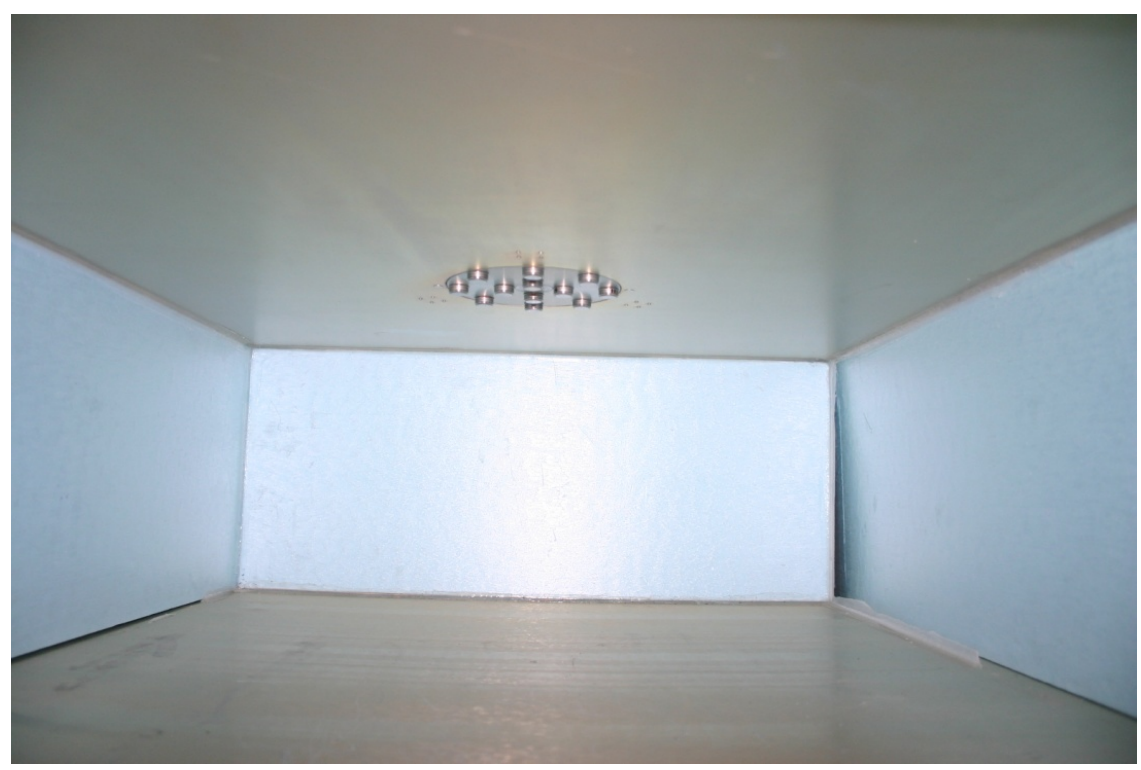

Figure 4. View of iButtons mounted in the TEM cell active volume.

After the frequency span of the TEM cell was exceeded the testing moved to the use of antennas. Figure 5 shows the equipment used for the higher power testing and the EMCO antenna.

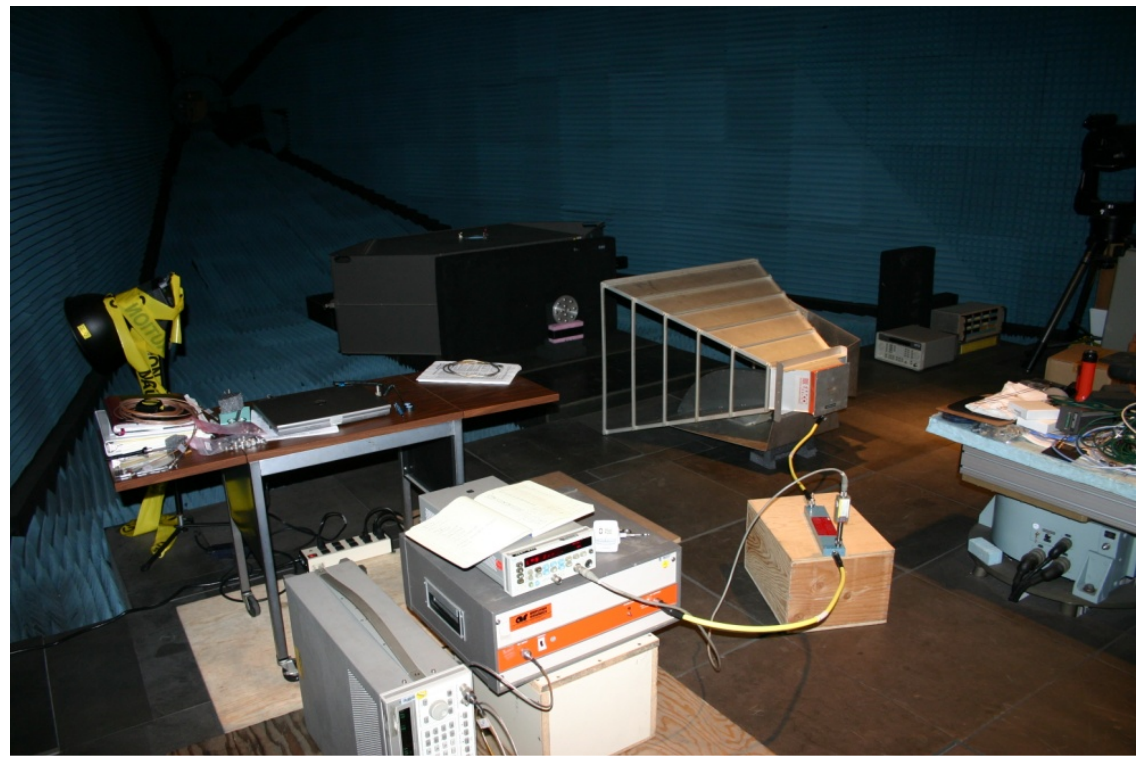

Figure 5. Test equipment assembly for higher power illumination using the Amplifier Research antennas

\section{NEW IBUTTONS}

The matrix of test conditions for the 'new' iButtons is shown in Table A2 in the Appendix. The sampling rate for these tests were set to 1 second intervals to allow the curves to be generated, the 'old' iButton sampling rate was set to 300 seconds. After individual test sequences were completed the iButton data were downloaded and examined as the iButtons in the "old" ensemble were examined. RF upset of the operation of the device would possibly affect the operating parameters as well as corrupt the data. There are no unusual responses observed. 
The iButtons were also subjected to a temperature change using an incandescent light bulb as a heat source. Figure 6 shows the process and the results of two of the modules are plotted in Figure 7.

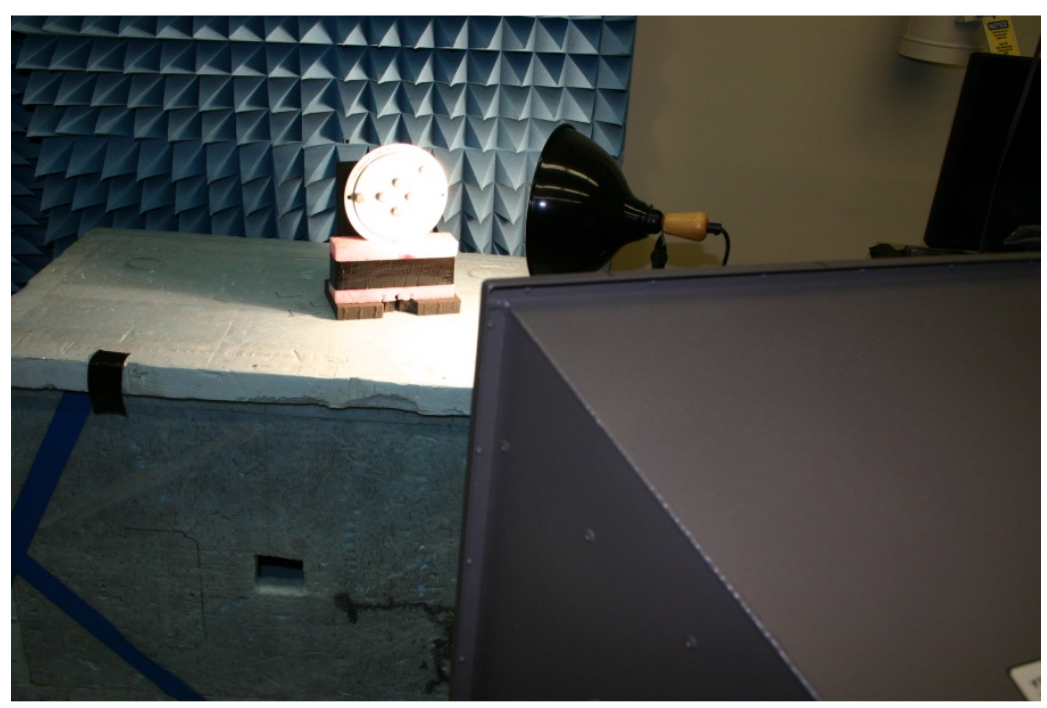

Figure 6. Semi-planar vertically polarized E-Fields were applied at higher power levels using AR antennas.

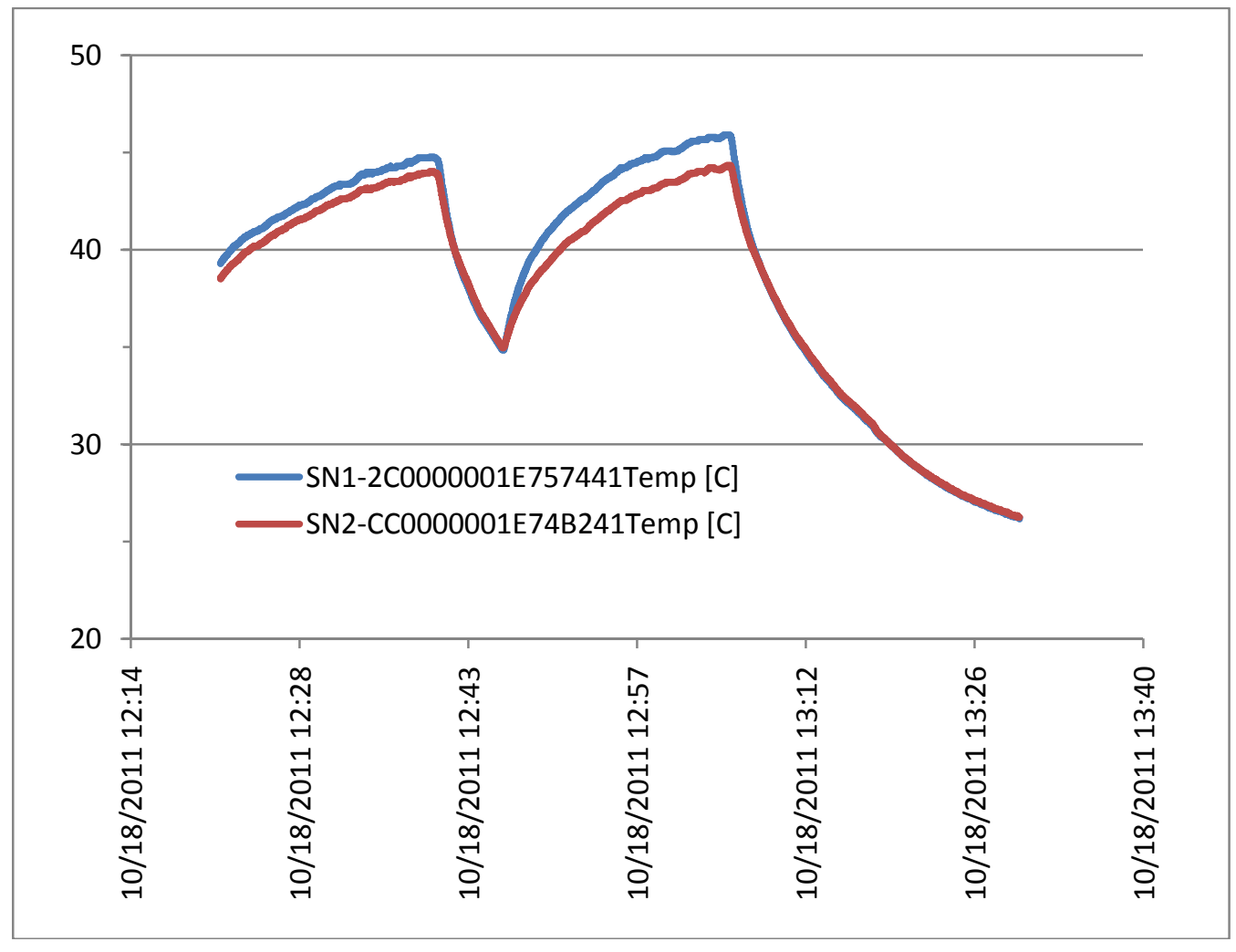

Figure 7. Temperature variation, frequency sweep and orientations are changed. Only two iButton modules are shown from a set of 6 . 


\section{DISCUSSION}

There is no indication that the RF energy influenced the operation or the data acquired by the iButton. We did not expressly examine the least significant bits of the data, these might be susceptible to the RF energy if they are the most sensitive portion of the modules circuitry. There is no upset observed and we further assumed that any upset in operation could involve any of the logic bits equally, this is not observed.

The physical structure of the iButton makes it a small coupling target for RF energy; the cap and body are physically close and without much extent where RF voltages and currents might be induced at the frequencies we examined. The possibility of coupling data to the iButton from operation of another piece of equipment is also remote, the iButton uses an internal oscillator operating at $32 \mathrm{kHz}$ which is not synchronized to anything and its highest writedata pulse timing is about $1 \mu$ s in duration and is externally controlled.

If it is necessary to further reduce the potential for RF coupling to the device then a shorting cap or a cover could be placed over the device. The 1-wire data interface allows the contact to be shorted to the case, placing a shield or cover over the device would be equally appropriate. 


\section{APPENDIX}

\section{TABLE A1}

\section{RF Susceptibility Study of DS1922L-iButton Temperature Logger}

Test Procedure for the Used iButtons:

Saved all the data stored in the iButtons that were previously used so comparison can be made after these iButtons were subjected to different RF power \& frequencies. Put 12 used iButtons in a circular metal plate (cover of the TEM cell).

Sweep @ 100kHz-150MHz inside AR-TC3020 TEM Cell using a 1W Power Amplifier for 200 seconds. Power input is $1 \mathrm{~W}$ and the distance of the septum to iButtons is 12 inches.

CW @ 100MHz-500MHz every 50MHz step inside AR-TC3020 TEM Cell using a 25W Power Amplifier. Test time is 60 seconds at each frequency. Power input is $25 \mathrm{~W}$ and the distance of the septum to iButtons is 12 inches.

CW @ 200MHz-1000MHz every 50MHz step using a 200MHz-2GHz antenna and a 25W Power Amplifier. Test time is 60 seconds at each frequency. Power input is $25 \mathrm{~W}$ at a distance of 1 meter.

No Sweep @100MHz-1000MHz due to sensitivity of the power amplifier causing power trip.

CW @ 1-1.5GHz every $100 \mathrm{MHz}$ step using a $200 \mathrm{MHz}-2 \mathrm{GHz}$ antenna and a $100 \mathrm{~W}$ Power Amplifier. Test time is 60 seconds at each frequency. Power input is $25 \mathrm{~W}$ at a distance of 1 meter.

Sweep @ 1-1.5GHz using a 200MHz-2GHz antenna and a 100W Power Amplifier for 200 seconds. Power inputs are $25 W \& 50 W$ at a distance of 1 meter.

CW @ 1.5-3G Hz every $100 \mathrm{MHz}$ step using a $0.8-5.2 \mathrm{GHz}$ antenna and an $85 \mathrm{~W}$ Power Amplifier. Test time is 60 seconds at each frequency. Power input is $25 \mathrm{~W}$ at a distance of 1 meter.

Sweep @ 1.5-2GHz using a 0.8-5.2GHz antenna and an 85W Power Amplifier for 200 seconds. Power inputs are $25 W \& 50 W$ at a distance of 1 meter.

Sweep @ 2-2.5GHz using a 0.8-5.2GHz antenna and an 85W Power Amplifier for 200 seconds. Power inputs are $25 W \& 50 W$ at a distance of 1 meter.

Sweep @ 2.5-2.99GHz using a 0.8-5.2GHz antenna and an 85W Power Amplifier for 200 seconds. Power inputs are $25 W \& 50 W$ at a distance of 1 meter.

Overall Results:

All of the above tests have no effect on memory data log, clock timing, mission status, \& mission temperature data log that we initially downloaded before iButtons were subjected to different RF power \& frequencies. 
TABLE A2

\section{Matrix of test conditions}

100k-1.5G Room Temperature Inside Anechoic Chamber

\begin{tabular}{|c|c|c|c|c|c|c|c|}
\hline $\begin{array}{c}\text { RF } \\
\text { ON/OFF }\end{array}$ & Frequency & Sweep/CW & $\begin{array}{l}\text { Sweep/Duration } \\
\text { Time (seconds) }\end{array}$ & Date/Start Time & Plate Orientation & Power & Antenna \\
\hline OFF & & & & 10/17/2011 10:34 & & & \\
\hline ON & $1.0 \mathrm{G}-1.5 \mathrm{G}$ & Sweep & 200 & 10/17/2011 10:40 & Front & $50 \mathrm{~W}$ & EMCO \\
\hline ON & $1.0 \mathrm{G}-1.5 \mathrm{G}$ & Sweep & 200 & 10/17/2011 10:50 & Sideway & $50 W$ & EMCO \\
\hline ON & $200 M$ & $\mathrm{CW}$ & 60 & 10/17/2011 12:02 & Front & $25 W$ & EMCO \\
\hline ON & $250 \mathrm{M}$ & $\mathrm{CW}$ & 60 & 10/17/2011 12:04 & Front & $25 \mathrm{~W}$ & EMCO \\
\hline ON & $300 \mathrm{M}$ & CW & 60 & 10/17/2011 12:06 & Front & $25 W$ & EMCO \\
\hline ON & $350 M$ & CW & 60 & 10/17/2011 12:08 & Front & $25 W$ & EMCO \\
\hline ON & $400 \mathrm{M}$ & $\mathrm{CW}$ & 60 & 10/17/2011 12:11 & Front & $25 \mathrm{~W}$ & EMCO \\
\hline ON & $450 \mathrm{M}$ & CW & 60 & 10/17/2011 12:13 & Front & $25 \mathrm{~W}$ & EMCO \\
\hline ON & $500 M$ & CW & 60 & 10/17/2011 12:15 & Front & $25 W$ & EMCO \\
\hline ON & $550 \mathrm{M}$ & CW & 60 & 10/17/2011 12:17 & Front & $25 \mathrm{~W}$ & EMCO \\
\hline ON & $600 \mathrm{M}$ & $\mathrm{CW}$ & 60 & 10/17/2011 12:19 & Front & $25 W$ & EMCO \\
\hline ON & $650 M$ & $\mathrm{CW}$ & 60 & 10/17/2011 12:21 & Front & $25 W$ & EMCO \\
\hline ON & $700 \mathrm{M}$ & $\mathrm{CW}$ & 60 & $10 / 17 / 2011$ 12:23 & Front & $25 W$ & EMCO \\
\hline ON & $750 \mathrm{M}$ & CW & 60 & $10 / 17 / 201112: 25$ & Front & $25 W$ & EMCO \\
\hline ON & $800 \mathrm{M}$ & CW & 60 & $10 / 17 / 2011$ 12:27 & Front & $25 W$ & EMCO \\
\hline ON & $850 M$ & CW & 60 & 10/17/2011 12:29 & Front & $25 W$ & EMCO \\
\hline ON & $900 \mathrm{M}$ & $\mathrm{CW}$ & 60 & 10/17/2011 12:31 & Front & $25 W$ & EMCO \\
\hline ON & $950 \mathrm{M}$ & $\mathrm{CW}$ & 60 & 10/17/2011 12:33 & Front & $25 \mathrm{~W}$ & EMCO \\
\hline ON & $1000 \mathrm{M}$ & CW & 60 & 10/17/2011 12:35 & Front & $25 W$ & EMCO \\
\hline ON & $200 \mathrm{M}$ & $\mathrm{CW}$ & 60 & $10 / 17 / 2011$ 12:43 & Sideway & $25 \mathrm{~W}$ & EMCO \\
\hline ON & $250 \mathrm{M}$ & CW & 60 & 10/17/2011 12:46 & Sideway & $25 \mathrm{~W}$ & EMCO \\
\hline ON & $300 \mathrm{M}$ & CW & 60 & 10/17/2011 12:48 & Sideway & $25 W$ & EMCO \\
\hline ON & $350 \mathrm{M}$ & $\mathrm{CW}$ & 60 & 10/17/2011 12:50 & Sideway & $25 \mathrm{~W}$ & EMCO \\
\hline ON & $400 \mathrm{M}$ & CW & 60 & 10/17/2011 12:52 & Sideway & $25 W$ & EMCO \\
\hline ON & $450 \mathrm{M}$ & CW & 60 & $10 / 17 / 2011$ 12:54 & Sideway & $25 \mathrm{~W}$ & EMCO \\
\hline ON & $500 \mathrm{M}$ & CW & 60 & 10/17/2011 12:56 & Sideway & $25 \mathrm{~W}$ & EMCO \\
\hline ON & $550 \mathrm{M}$ & CW & 60 & $10 / 17 / 201112: 58$ & Sideway & $25 \mathrm{~W}$ & EMCO \\
\hline ON & $600 \mathrm{M}$ & CW & 60 & 10/17/2011 13:00 & Sideway & $25 \mathrm{~W}$ & EMCO \\
\hline ON & $650 \mathrm{M}$ & CW & 60 & 10/17/2011 13:02 & Sideway & $25 \mathrm{~W}$ & EMCO \\
\hline ON & $700 \mathrm{M}$ & CW & 60 & 10/17/2011 13:04 & Sideway & $25 W$ & EMCO \\
\hline ON & $750 \mathrm{M}$ & CW & 60 & 10/17/2011 13:06 & Sideway & $25 \mathrm{~W}$ & EMCO \\
\hline ON & $800 \mathrm{M}$ & CW & 60 & 10/17/2011 13:08 & Sideway & $25 \mathrm{~W}$ & EMCO \\
\hline ON & $850 \mathrm{M}$ & CW & 60 & 10/17/2011 13:10 & Sideway & $25 \mathrm{~W}$ & EMCO \\
\hline ON & $900 \mathrm{M}$ & CW & 60 & 10/17/2011 13:12 & Sideway & $25 \mathrm{~W}$ & EMCO \\
\hline ON & $950 \mathrm{M}$ & CW & 60 & 10/17/2011 13:14 & Sideway & $25 W$ & EMCO \\
\hline
\end{tabular}


Unclassified

\begin{tabular}{|c|c|c|c|c|c|c|c|c|}
\hline ON & $1000 \mathrm{M}$ & $\mathrm{CW}$ & 60 & 10/17/2011 13:16 & Sideway & $25 \mathrm{~W}$ & EMCO & \\
\hline ON & $100 \mathrm{M}$ & CW & 60 & 10/17/2011 13:21 & --- & $25 \mathrm{~W}$ & $\begin{array}{l}\text { TEM } \\
\text { Cell }\end{array}$ & \\
\hline ON & $150 M$ & $\mathrm{CW}$ & 60 & $10 / 17 / 2011$ 13:23 & --- & $25 \mathrm{~W}$ & $\begin{array}{l}\text { TEM } \\
\text { Cell }\end{array}$ & \\
\hline ON & $200 M$ & $\mathrm{CW}$ & 60 & $10 / 17 / 2011$ 13:25 & --- & $25 \mathrm{~W}$ & $\begin{array}{l}\text { TEM } \\
\text { Cell }\end{array}$ & \\
\hline ON & $250 M$ & $\mathrm{CW}$ & 60 & $10 / 17 / 2011$ 13:27 & --- & $25 \mathrm{~W}$ & $\begin{array}{l}\text { TEM } \\
\text { Cell }\end{array}$ & \\
\hline ON & $100 \mathrm{k}-150 \mathrm{M}$ & Sweep & 200 & $10 / 17 / 2011$ 13:38 & --- & $1 \mathrm{~W}$ & $\begin{array}{r}\text { TEM } \\
\text { Cell }\end{array}$ & \\
\hline \multirow[t]{2}{*}{ ON } & $1.5 \mathrm{G}-2 \mathrm{G}$ & Sweep & 200 & $10 / 17 / 2011$ 13:55 & Front & $50 \mathrm{~W}$ & $A R$ & $\begin{array}{c}\text { Room } \\
105\end{array}$ \\
\hline & & & $\begin{array}{c}\text { Last Temperature } \\
\text { Data Taken }\end{array}$ & $10 / 17 / 201113: 58$ & & & & \\
\hline
\end{tabular}

1.5G-3G Room Temperature (Room 105)

\begin{tabular}{|c|c|c|c|c|c|c|c|}
\hline $\begin{array}{c}\text { RF } \\
\text { ON/OFF }\end{array}$ & Frequency & Sweep/CW & $\begin{array}{l}\text { Sweep/Duration } \\
\text { Time (seconds) }\end{array}$ & Date/Start Time & Plate Orientation & Power & Antenna \\
\hline OFF & & & & $10 / 18 / 20118: 30$ & & & \\
\hline ON & $1.5 \mathrm{G}-2 \mathrm{G}$ & Sweep & 200 & $10 / 18 / 20118: 35$ & Front & $50 W$ & $A R$ \\
\hline ON & $2 \mathrm{G}-2.5 \mathrm{G}$ & Sweep & 200 & $10 / 18 / 20118: 40$ & Front & $50 W$ & $A R$ \\
\hline ON & $\begin{array}{c}2.5 \mathrm{G}- \\
2.999 \mathrm{G}\end{array}$ & Sweep & 200 & 10/18/2011 8:45 & Front & $50 W$ & $A R$ \\
\hline ON & $1.5 G-2 G$ & Sweep & 200 & $10 / 18 / 20118: 50$ & Sideway & $50 W$ & $A R$ \\
\hline ON & $2 \mathrm{G}-2.5 \mathrm{G}$ & Sweep & 200 & $10 / 18 / 20118: 55$ & Sideway & $50 W$ & AR \\
\hline ON & $\begin{array}{c}2.5 \mathrm{G}- \\
2.999 \mathrm{G}\end{array}$ & Sweep & 200 & 10/18/2011 9:00 & Sideway & $50 W$ & AR \\
\hline
\end{tabular}

1.5G-3G With Lamp Light (Room 105)

\begin{tabular}{|c|c|c|c|c|c|c|c|}
\hline $\begin{array}{c}\text { RF } \\
\text { ON/OFF }\end{array}$ & Frequency & Sweep/CW & $\begin{array}{l}\text { Sweep/Duration } \\
\text { Time (seconds) }\end{array}$ & Date/Start Time & Plate Orientation & Power & Antenna \\
\hline OFF & & & & $10 / 18 / 201112: 22$ & & & \\
\hline ON & $1.5 \mathrm{G}-2 \mathrm{G}$ & Sweep & 200 & $10 / 18 / 201112: 25$ & Front & $50 W$ & $A R$ \\
\hline ON & $2 \mathrm{G}-2.5 \mathrm{G}$ & Sweep & 200 & 10/18/2011 12:31 & Front & $50 W$ & $A R$ \\
\hline ON & $\begin{array}{c}2.5 \mathrm{G}- \\
2.999 \mathrm{G}\end{array}$ & Sweep & 200 & 10/18/2011 12:37 & Front & $50 W$ & AR \\
\hline ON & $1.5 \mathrm{G}-2 \mathrm{G}$ & Sweep & 200 & $10 / 18 / 201112: 50$ & Sideway & $50 W$ & $A R$ \\
\hline ON & $2 \mathrm{G}-2.5 \mathrm{G}$ & Sweep & 200 & $10 / 18 / 2011$ 12:56 & Sideway & $50 W$ & $A R$ \\
\hline ON & $\begin{array}{c}2.5 \mathrm{G}- \\
2.999 \mathrm{G}\end{array}$ & Sweep & 200 & 10/18/2011 13:02 & Sideway & $50 W$ & AR \\
\hline
\end{tabular}




\section{TABLE A3}

\section{Equipment Used for the Measurement:}

AR-1W1000

AR-25W1000M7

PST-1929-100

EMPOWER-2122BBS4K6AJO

AR-TC3020

EMCO-3106

AR-AT4002A

Narda-3022

Narda-3020A

HP-8481H

HP-8481A

HP-438A

HP-8665A
1W 100kHz-1GHz Power Amplifier 25W 100-1000MHz Power Amplifier 100W 1-2G Hz Power Amplifier $85 \mathrm{~W}$ 1.5-3G Hz Power Amplifier DC-375MHz TEM Cell 200MHz-2GHz Antenna 0.8-5.2 $\mathrm{GHz}$ Horn Antenna 1-4GHz Bi-Directional Coupler $50-1000 \mathrm{MHz}$ Bi-Directional Coupler High Power Sensor Power Sensor

Power Meter

0.1-4200MHz RF Signal Generator

\section{TABLE A4}

\section{Antenna Electric Field Estimates}

The following table summarizes the field strengths used for this evaluation.

\section{TEM CELL}

$\begin{array}{lll}100 \mathrm{kHz}-150 \mathrm{MHz} & 1 \mathrm{~W} & 63 \mathrm{~V} / \mathrm{m} \\ 100 \mathrm{MHz}-500 \mathrm{MHz} & 25 \mathrm{~W} & 318 \mathrm{~V} / \mathrm{m}\end{array} \quad 375 \mathrm{MHz}$ maximum for the TEM cell uniform field

\section{EMCO ANTENNA}

\begin{tabular}{|c|c|c|c|}
\hline $200 \mathrm{MHz}-1 \mathrm{GHz}$ & $25 \mathrm{~W}$ & $68 \mathrm{~V} / \mathrm{m}$ & \\
\hline $1.0 \mathrm{GHz}-1.5 \mathrm{GHz}$ & $25 \mathrm{~W} / 50 \mathrm{~W}$ & $68 \mathrm{~V} / \mathrm{m}$ & approximation since gain varies significantly \\
\hline \multicolumn{4}{|c|}{ AMPLIFIER RESEARCH ANTENNA } \\
\hline $1.5 \mathrm{GHz}-2.0 \mathrm{GHz}$ & $25 \mathrm{~W} / 50 \mathrm{~W}$ & $120-150 \mathrm{~V} / \mathrm{m}$ & $25 \mathrm{~W}$ level estimate, gain higher at higher frequency \\
\hline $2.0 \mathrm{GHz}-2.5 \mathrm{GHz}$ & $25 \mathrm{~W} / 50 \mathrm{~W}$ & $180-220 \mathrm{~V} / \mathrm{m}$ & \\
\hline $2.5 \mathrm{GHz}-2.99 \mathrm{GHz}$ & $25 \mathrm{~W} / 50 \mathrm{~W}$ & $220-270 \mathrm{~V} / \mathrm{m}$ & \\
\hline
\end{tabular}

